University of New Mexico

UNM Digital Repository

10-28-1999

\title{
Allometric scaling of production and life-history variation in vascular plants
}

Brian Enquist

Geoffrey West

Eric Charnov

James Brown

Follow this and additional works at: https://digitalrepository.unm.edu/biol_fsp

Part of the Biology Commons

\section{Recommended Citation}

Enquist, B.J., G.B. West, E.L. Charnov and J.H. Brown. 1999. Allometric scaling of production and lifehistory variation in vascular plants. Nature 401:907-911

This Article is brought to you for free and open access by the Academic Department Resources at UNM Digital Repository. It has been accepted for inclusion in Biology Faculty \& Staff Publications by an authorized administrator of UNM Digital Repository. For more information, please contact disc@unm.edu. 
1958-88 (see above). Matching data from 8 trees sampled on the east end of Isle Royale, where balsam fir are not heavily or repeatedly browsed by moose ${ }^{10}$, provided a natural control for the test of our hypothesis relating climate and wolf behaviour to the dynamics of moose and fir growth. On the east end, fir growth did not correlate with the NAO index at lags of $0(r=0.074, P=0.69)$ or 1 year $(r=0.069, P=0.71)$ or with moose density at a lag of 1 year $(r=0.054, P=0.78)$.

\section{The North Atlantic Oscillation}

The NAO is a meridional alternation in atmospheric mass balance between pressure centres over the Azores and Iceland. The winter NAO index is calculated on the basis of the normalized sea-level pressure difference between these two centres from December to March $^{17}$. A negative difference indicates weak westerly winds across the Atlantic Ocean and unusually warm winters over north eastern North America; opposing conditions prevail during positive years ${ }^{17}$. We used data from the Climate Indices website of the National Center for Atmospheric Research, Boulder, USA (http://www.cgd.ucar.edu/cas/climind/). Although annual snow depth measures during the study period are not available for Isle Royale, the NAO index correlates negatively with snow depth in nearby Superior National Forest, USA ${ }^{9}$. In all regressions, degrees of freedom for tests of significance of independent variables were adjusted for autocorrelation ${ }^{9}$.

Received 24 March; accepted 11 August 1999.

1. Estes, J. A. \& Palmisano, J. F. Sea otters: their role in structuring nearshore communities. Science $\mathbf{1 8 5}$ 1058-1060 (1974)

2. Spiller, D. A. \& Schoener, T. W. A terrestrial field experiment showing the impact of eliminating top predators on foliage damage. Nature 347, 469-472 (1990).

3. McPeek, M. A. The consequences of changing the top predator in a food web: a comparative experimental approach. Ecol. Monogr. 68, 1-23 (1998).

4. Sanford, E. Regulation of keystone predation by small changes in ocean temperature. Science 283, 2095-2097 (1999)

5. Paine, R. T. Food web complexity and species diversity. Am. Nat. 100, 65-75 (1966).

6. Paine, R. T. Intertidal community structure: Experimental studies on the relationship between a dominant competitor and its principal predator. Oecologia 15, 93-120 (1974).

7. Estes, J. A. \& Duggins, D. O. Sea otters and kelp forests in Alaska: generality and variation in a community ecological paradigm. Ecol. Monogr. 65, 75-100 (1995).

8. Estes, J. A., Tinker, M. T., Williams, T. M. \& Doak, D. F. Killer whale predation on sea otters linking oceanic and nearshore ecosystems. Science 282, 473-476 (1998).

9. Post, E. \& Stenseth, N. C. Large-scale climatic variability and population dynamics of moose and white-tailed deer. J. Anim. Ecol. 67, 537-543 (1998).

10. McLaren, B. E. \& Peterson, R. O. Wolves, moose, and tree rings on Isle Royale. Science 266, 1555-1558 (1994).

11. Peterson, R. O. WolfEcology and Prey Relationships on Isle Royale (National Park Services Scientific Ser. No. 11, Washington DC, 1977).

12. Peterson, R. O., Page, R. E. \& Dodge, K. M. Wolves, moose, and the allometry of population cycles Science 224, 1350-1352 (1984).

13. McLaren, B. E. \& Janke, R. A. Seedbed and canopy cover effects on balsam fir seedling establishment in Isle Royale National Park. Can. J. For. Res. 26, 782-793 (1996).

14. Brandner, T. A., Peterson, R. O. \& Risenhoover, K. L. Balsam fir on Isle Royale: effects of moose herbivory and population density. Ecology 71, 155-164 (1990).

15. McInnes, P. F., Naiman, R. J., Pastor, J. \& Cohen, Y. Effects of moose browsing on vegetation and litter of the boreal forest, Isle Royale, Michigan, USA. Ecology 73, 2059-2075 (1992).

16. Pastor, J., Dewey, B., Naiman, R. J., McInnes, P. F. \& Cohen, Y. Moose browsing and soil fertility in the boreal forests of the Isle Royale National Park. Ecology 74, 467-480 (1993).

17. Hurrell, J. W. Decadal trends in the North Atlantic Oscillation: regional temperatures and precipitation. Science 269, 676-679 (1995).

18. Mech, L. D., McRoberts, R. E., Peterson, R. O. \& Page, R. E. Relationship of deer and moose populations to previous winters' snow. J. Anim. Ecol. 56, 615-627 (1987).

19. Post, E. \& Stenseth, N. C. Climatic variability, plant phenology, and northern ungulates. Ecology 80, 1322-1339.

20. Peterson, R. O., Thomas, J. N., Thurber, J. M., Vucetich, J. A. \& Waite, T. A. Population limitation and the wolves of Isle Royale. J. Mamm. 79, 828-841 (1998).

21. Thurber, J. M. \& Peterson, R. O. Effects of population density and pack size on the foraging ecology of gray wolves. J. Mamm. 74, 870-889 (1993).

22. Schmidt, P. A. \& Mech, L. D. Wolf pack size and food acquisition. Am. Nat. 150, 513-517 (1997).

23. Peterson, R. O. \& Page, R. E. The rise and fall of Isle Royale wolves, 1975-1986. J. Mamm. 69, 89-99 (1988).

24. Peterson, R. O. \& Allen, D. L. Snow conditions as a parameter in moose-wolf relationships. Le Naturaliste Canadien 101, 481-492 (1974).

25. Kelsall, J. P. Structural adaptations of moose and deer for snow. J. Mamm. 50, 302-310 (1969).

26. Molvar, E. M. \& Bowyer, R. T. Moose herbivory, browse quality, and nutrient cycling in an Alaskan treeline community. Oecologia 94, 472-479 (1993).

27. Mech, L. D. The Wolf (Univ. Minnesota Press, 1970).

28. Ben-David, M., Bowyer, R. T., Duffy, L. K., Roby, D. D. \& Schell, D. M. Social behavior and ecosystem processes: river otter latrines and nutrient dynamics of terrestrial vegetation. Ecology 79, 2567-2571 (1998).

29. Beckerman, A. P., Uriarte, M. \& Schmitz, O. J. Experimental evidence for a behavior-mediated trophic cascade in a terrestrial food chain. Proc. Natl Acad. Sci. USA 94, 10735-10738 (1997).

30. Schmitz, O. J., Beckerman, A. P. \& O'Brien, K. M. Behaviorally mediated trophic cascades: effects of predation risk on food web interactions. Ecology 78, 1388-1399 (1997).

\section{Acknowledgements}

We thank the U.S. National Science Foundation for grants to E.P. and R.O.P., the US National Park Service and Earthwatch for grants to R.O.P. and the Norwegian Science Council (NFR) for a grant to N.C.S. We thank G.-P. Saetre for discussions.

Correspondence and requests for materials should be addressed to E.P.

(e-mail: eric.post@bio.uio.no).

\section{Allometric scaling of production and life-history variation in vascular plants}

\author{
Brian J. Enquist ${ }^{\star} \dagger$, Geoffrey B. West $\dagger \neq$, Eric L. Charnov $\S$ \\ \& James H. Browns $\dagger$
}

${ }^{*}$ National Center for Ecological Analysis and Synthesis, 735 State Street, Suite 300, Santa Barbara, California 93101-5504, USA

$\$$ Department of Biology, University of New Mexico, Albuquerque,

New Mexico 87131, USA

$\dagger$ The Santa Fe Institute, 1399 Hyde Park Road, Santa Fe, New Mexico 87501, USA $\ddagger$ Theoretical Division, T-8, MS B285, Los Alamos National Laboratory,

Los Alamos, New Mexico 87545, USA

A prominent feature of comparative life histories is the well documented negative correlation between growth rate and life $\operatorname{span}^{1,2}$. Patterns of resource allocation during growth and reproduction reflect life-history differences between species ${ }^{1,2}$. This is particularly striking in tropical forests, where tree species can differ greatly in their rates of growth and ages of maturity but still attain similar canopy sizes ${ }^{3,4}$. Here we provide a theoretical framework for relating life-history variables to rates of production, $\mathrm{d} M$ / $\mathrm{d} t$, where $M$ is above-ground mass and $t$ is time. As metabolic rate limits production as an individual grows, $\mathrm{d} M / \mathrm{d} t \propto M^{3 / 4}$. Incorporating interspecific variation in resource allocation to wood density, we derive a universal growth law that quantitatively fits data for a large sample of tropical tree species with diverse life histories. Combined with evolutionary life-history theory ${ }^{1}$, the growth law also predicts several qualitative features of tree demography and reproduction. This framework also provides a general quantitative answer to why relative growth rate $(1 / M)(\mathrm{d} M / \mathrm{d} f)$ decreases with increasing plant size $\left(\propto M^{-1 / 4}\right)$ and how it varies with differing allocation strategies ${ }^{5-8}$.

Coexistence in diverse ecological communities has been thought to be due, in part, to life-history trade-offs involving allocation of resources ${ }^{6,9-13}$. There is, however, no generally accepted mechanistic framework for understanding how patterns of allocation influence variation in life histories. Here we show that a general allometric growth model for trees can provide an explanation for much life-history variation. Metabolism produces the energy and materials that are used for all biological processes. A central issue of life history is how over ontogeny the products of metabolism are allocated among maintenance, growth and reproduction. Previous work has shown how the 3/4-power scaling of metabolic rate with body mass in both animals and plants results from physical and biological constraints on the distribution of resources through fractal-like vascular networks ${ }^{14-16}$.

In Box 1, we derive a production/growth law in terms of aboveground plant mass, $M$, or basal stem diameter, $D$. Our data set (Table 1, Fig. 1) consists of a 20-year change in $D(D(20)$ compared with $D(0))$ for 45 species of trees in a tropical dry forest. In total, there were 2,283 individuals, all of reproductive age. Equation (6) predicts that $D^{2 / 3}(20)=A_{i}+D^{2 / 3}(0)$, so that a plot of $D^{2 / 3}(20)$ versus $D^{2 / 3}(0)$ for each species should yield a straight line with a universal slope of unity and an intercept, $A_{i}$, inversely proportional to wood density, $\rho$, so that $A_{i}$ is proportional to $\rho^{-1}$. We tested this prediction by analysing the data for 45 species (Fig. $2 \mathrm{a}$, Table 1 ). The average slope of all species, 1.04 , is essentially not different from the predicted value of 1.0 ( $95 \%$ confidence intervals (CI): 1.01 to 1.08). Forty of the forty-five species had slopes statistically indistinguishable from the predicted value of 1 (Table 1). There was no systematic trend to deviate above or below 1; furthermore, we expect $5 \%$ ( $\approx 2.5$ species $)$ to differ by chance alone at the 0.05 level. 
We conclude that production within species scales as $M^{3 / 4}$. There is, however, considerable interspecific variation in the intercepts. From Box 1, the intercepts should be inversely proportional to wood density, $\rho$, and this is confirmed by regression analysis $(r=-0.468$, exponent $=-0.934,95 \% \mathrm{CI}:-1.631$ to -0.237 , intercept $=0.6196, n=29$ ). Weighting each species by multiplying $D^{2 / 3}$ by $\rho$ collapses the production relationships for each species onto a line with a universal slope of unity and a common intercept (see Fig. 2b and equation (6)). Essentially, there is a trade-off in growth rate (change in stem diameter) with allocation to tissue density: species that allocate less biomass to their stems (light woods) increase in basal diameter faster than species that allocate more to stems (dense woods).

The trees depicted in Fig. $2 \mathrm{a}$ are reproducing, so some proportion of production, $\lambda$, must be allocated to reproduction rather than growth. The derivation in Box 1 (resulting in equation (7)) and measured empirical reproductive allometries both suggest that $\lambda$ is independent of size within a species. To obtain the convergence of allometries implied in Fig. $2 \mathrm{~b}$ requires the stronger constraint that $\lambda$ be the same across species. Studies reporting relationships between production of reproduction mass and stem diameter indicate that whereas measured exponents usually approximate to the predicted value of 2 , there are differences in normalization constants, and hence in $\lambda$, among species ${ }^{17-20}$. Such variation will not change the predicted slope of unity when data are plotted as in Fig. 2a. If this variation in $\lambda$ is independent of $\rho$, however, it will show up as residual variation in plots such as Fig. $2 \mathrm{~b}$.

Production data for seven species of temperate trees provide additional evidence that $\mathrm{d} M / \mathrm{d} t$ is proportional to $M^{3 / 4}$. Instead of measuring change in diameter, Whittaker and Woodwell ${ }^{21}$ recorded total annual mass production of leaves and twigs, and bark and stem wood as a function of trunk diameter. Relating trunk diameter to annual production for twig and leaf mass, and wood and bark mass, shows that both scale with exponents essentially indistinguishable from the predicted $M^{3 / 4}$. So mass production in both tropical and temperature trees scales as $M^{3 / 4}$.

Relative growth rate $(1 / M)(\mathrm{d} M / \mathrm{d} t)$ decreases with increases in individual size and varies across species ${ }^{5-8}$. Although this decrease has been qualitatively attributed to several mechanisms ${ }^{6}$, a quantitative rule emerges as a direct consequence of equations (2) and (3): $(1 / M)(\mathrm{d} M / \mathrm{d} t) \propto M^{-1 / 4}$. This rule is predicted to hold even across species growing in the same environment for comparisons when

Box 1

\section{The growth law}

As trees continue to increase in size throughout life, and this growth must be fuelled by metabolism, it is reasonable to assume that the growth rate (the rate at which its mass, $M$, increases over time), is directly proportional to metabolic rate, $B$, (the rate of gross photosynthesis). Thus, at any time $t$,

$$
\frac{\mathrm{d} M}{\mathrm{~d} t}=C_{\mathrm{G}} B
$$

where $C_{G}$ is a proportionality constant that can be time dependent. It has been shown that $B$ is proportional to $V^{3 / 4}$, and stem diameter, $D$, is proportional to $V^{3 / 8}$, where $V$ is the total volume of the plant ${ }^{14}$. If $\rho=(M I V)$ is the tissue- or species-specific wood density, then, at any time $t$, these can be expressed as

$$
B=C_{B}\left(\frac{M}{\rho}\right)^{3 / 4} \quad D=C_{D}\left(\frac{M}{\rho}\right)^{3 / 8}
$$

where $C_{B}$ and $C_{D}$ are corresponding proportionality constants. Implicit in these results is the assumption that the ratio $E / \rho$, where $E$ is the Young's modulus of elasticity, is constant for all plants ${ }^{18}$. Here, we relax the restriction implicit in ref. 14 that $\rho$ is constant and allow it to differ among plant species and to vary with time. Equations (2) and (3) can be combined to give

$$
\frac{\mathrm{d} D}{\mathrm{~d} t}=\left(\frac{3 C}{2 \rho}\right) D^{1 / 3}
$$

where $C \equiv 1 / 4 C_{G} C_{B} C_{D}^{2 / 3}$. This can be integrated to give

$$
D(t)^{2 / 3}-D\left(t_{0}\right)^{2 / 3}=\int_{t_{0}}^{t} \frac{C(t)}{\rho(t)} \mathrm{d} t
$$

where the time dependence of all variables has been made explicit and the integration has been carried out from some initial time, $t_{0}$, up to some arbitrary time, $t$. Thus, regardless of any possible time dependence of either the proportionality constants or the density, a plot of $D^{2 / 3}(t)$ versus $D^{2 / 3}\left(t_{0}\right)$ for fixed times $t$ and $t_{0}$ for any species should yield a straight line with a universal slope of unity but with an intercept that depends on the time interval and the species. If, however, $\rho$ of a given plant is taken to be independent of time, but allowed to vary across species, this can be re-expressed as

$$
\rho\left[D(t)^{2 / 3}-D\left(t_{0}\right)^{2 / 3}\right]=\int_{t_{0}}^{t} C(t) \mathrm{d} t
$$

The intercept of the production relationship should therefore be inversely proportional to $\rho$. If $C_{G}, C_{B}$, and $C_{D}$ are independent of time then the intercept, namely the righthand side of equation (6), is given by $C\left(t-t_{0}\right)$. Furthermore, if $C$ does not vary among species as implicitly assumed in ref. 14 , and the time interval is the same for all species, then weighting $D^{2 / 3}(t)$ and $D^{2 / 3}\left(t_{0}\right)$ by $\rho$ should collapse all species onto a universal line of unit slope. The intercept should no longer depend upon the species but only upon the time interval and $C$ (however, see below for the reproductive period).

This framework allows us to recast the mass-production law as a function of basal stem diameter, $D$,

$$
\frac{\mathrm{d} M}{\mathrm{~d} t}=\left(\frac{C_{\mathrm{G}} C_{B}}{C_{D}^{2}}\right) D^{2}
$$

This gives the new prediction that across species, $d M / d t$, for trees of the same diameter is explicitly independent of wood density $\rho$

The derivation so far has assumed that the plant is not reproducing, so that all production is given to growth. Growth must, however, slow with the onset of reproduction ${ }^{1}$, as some fraction of production, $(\lambda) \mathrm{d} M / \mathrm{d} t$, is then devoted to reproduction rather than to individual growth, $(1-\lambda) \mathrm{d} / M / \mathrm{d} t$. The scaling rule for reproductive allocation and growth after the onset of reproduction depends upon the behaviour of $\lambda$. Life-history theor $y^{1,2}$ predicts the age (size) course of this reproductive allocation. The simplest model is to take $\lambda$ as a constant both within and across species. A constant $\lambda$ within species is supported by several studies ${ }^{17-20}$ that have measured allometries for the biomass of reproductive organs, $M_{\mathrm{R}}$, versus stem diameter, $D$, in both angiosperms and gymnosperms. $M_{R}$ reflects the rate of allocation to reproduction. Since published studies show that $M_{R}$ is generally proportional to $D^{2}$, it follows from equation (7) that $M_{\mathrm{R}}$ is proportional to $\mathrm{d} M / \mathrm{d} t$ indicating that $\lambda$ is indeed approximately a constant within species and independent of size. This is an important result, as animals have $\lambda$ increasing from 0 to 1 over the reproductive period ${ }^{1,2}$. The fact that trees appear to have nearly constant values of $\lambda$ probably reflects the constraints of resource harvesting and biomechanics on plant growth and development. Note that if $\lambda$ is approximately constant, all of the previous growth results are true for all time periods $\left(t-t_{0}\right)$ after the onset of reproduction, with $C_{G}$ redefined to be $(1-\lambda) C_{G}$. 
wood density is held constant.

The simplest life-history theory assumes determinate growth: at the onset of reproduction all production $(\lambda=1)$ is given to reproduction and growth ceases ${ }^{1}$. If we approximate plant growth in this way and assume a pre-reproductive production rate $\mathrm{d} M / \mathrm{d} t=C_{\mathrm{G}} B=C_{\mathrm{G}} C_{B}(M / \rho)^{3 / 4}$ as in equations (2) and (3), and if mortality rate is independent of plant size (over a range which includes possible sizes at maturation), well known arguments ${ }^{1}$ for

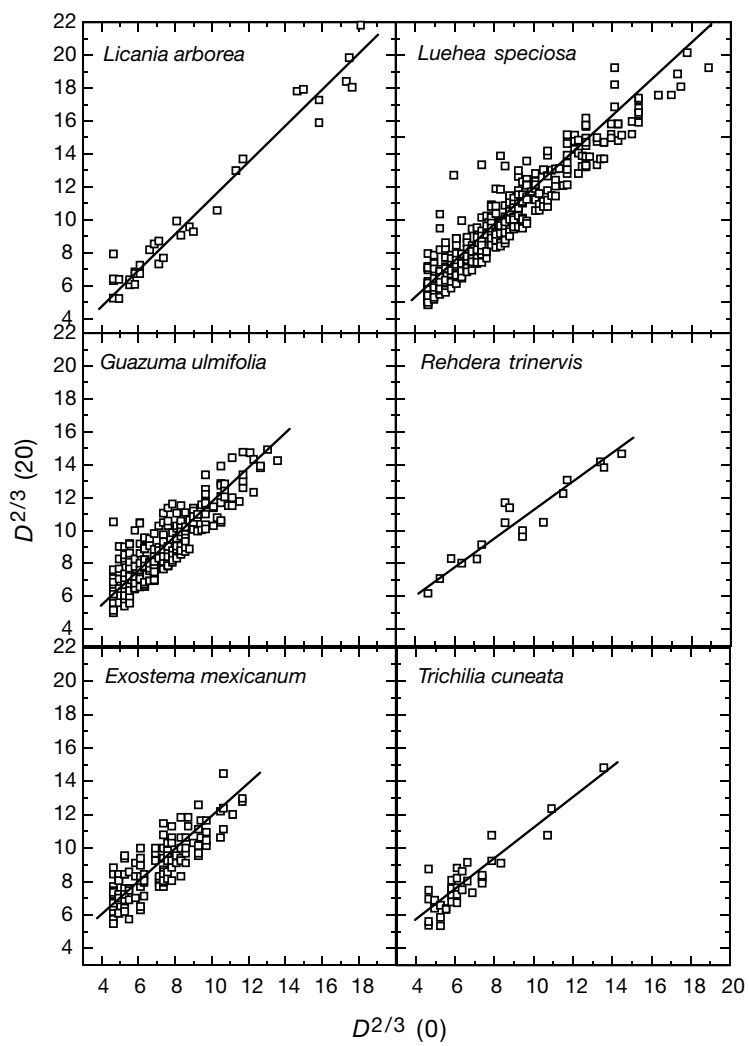

Figure 1 Representative variation of $D^{2 / 3}(0)$ versus $D^{2 / 3}(20)$ for six species of tropical trees. When sample sizes are large, the apparent variation is exaggerated because of the overlap of many points. Values for slopes and $r^{2}$ for these species are given in Table 1.

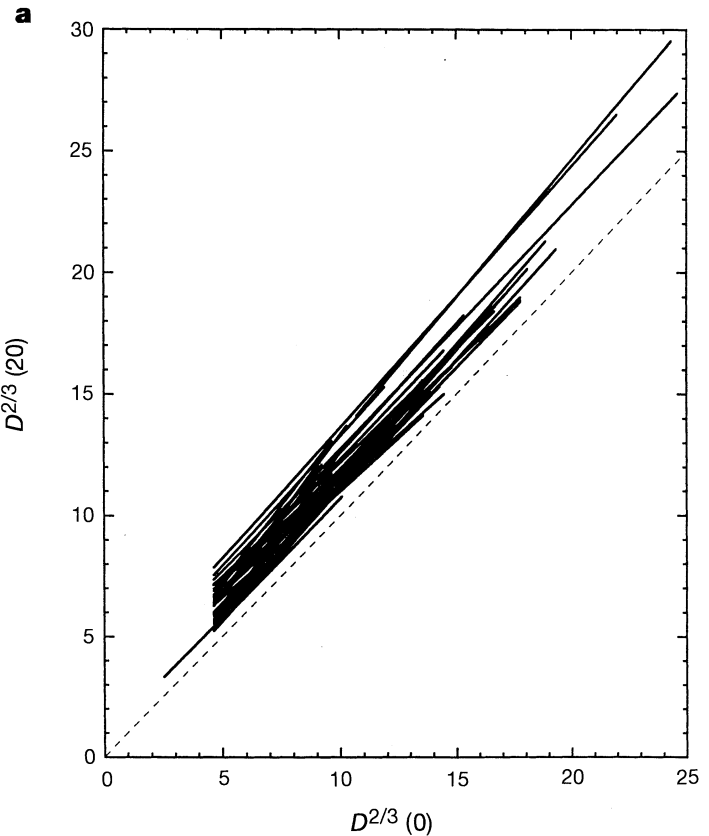

Figure 2 Growth rates of multiple species of tropical forest trees. a, $D^{2 / 3}(0)$ versus $D^{2 / 3}(20)$ for 45 species of dry forest trees. If production rate scales as $M^{3 / 4}$ (equation (2)), a slope of 1 (equation (5)) should be obtained. Note that all species have slopes that are essentially indistinguishable from 1 , represented by the dashed line of unity. Statistics for each species are reported in Table 1. b, Weighting each species production

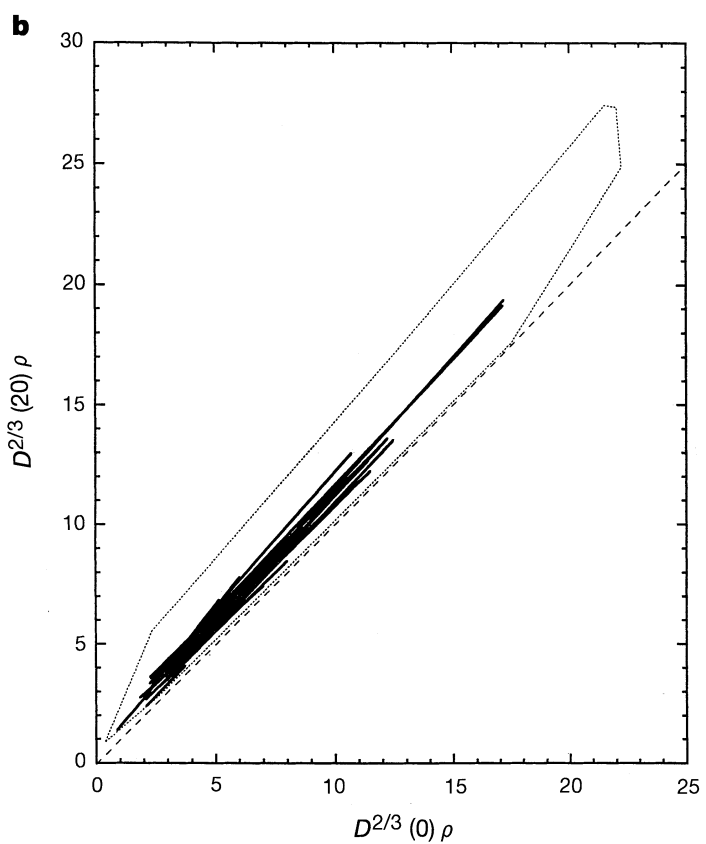

$D(20)^{2 / 3}=A_{1}+D(0)^{2 / 3}$ by wood density, $\rho$, collapses its production relationship onto a common line with unit slope and intercept $A$ (see equation (6)). The dotted box shows the much greater range of variation represented in Fig. 2a. The coefficient of variation of variation for intercepts is reduced, as predicted, from 65.8 to 54.33 . 


\begin{tabular}{|c|c|c|c|c|c|c|c|}
\hline Species & Family & $n$ & $\rho$ & Slope & Intercept & $r^{2}$ & $95 \%$ \\
\hline Agonandra macrocarpa L.O. Wms. & Opiliaceae & 19 & 0.74 & 0.978 & 1.484 & 0.874 & $0.759-1.196$ \\
\hline Albizzia adinocephala (Donn.Sm.) Britt. \& Rose & Fabaceae & 13 & - & 1.059 & 1.521 & 0.685 & $0.664-1.453$ \\
\hline Allophyllus occidentalis (Sw.) Radlk. & Sapindaceae & 7 & - & 0.987 & 0.840 & 0.820 & $0.505-1.470$ \\
\hline Annona reticulata $\mathrm{L}$. & Annonaceae & 13 & 0.57 & 0.981 & 1.046 & 0.826 & $0.709-1.252$ \\
\hline Astronium graveolens Jacq. & Anacardiaceae & 73 & 0.74 & 0.994 & 1.127 & 0.903 & $0.921-1.067$ \\
\hline Ateleia herbert-smithii Pittier & Fabaceae & 24 & - & 1.008 & 1.854 & 0.935 & $0.894-1.121$ \\
\hline Bombacopsis quinata (Jacq.) Dugand & Bombaceae & 23 & 0.47 & 1.000 & 2.327 & 0.649 & $0.731-1.269$ \\
\hline Bursera simaruba (L.) Sarg. & Burseraceae & 191 & 0.495 & 0.935 & 2.838 & 0.812 & $0.877-1.000$ \\
\hline Calycophyllum candidissimum (Vahl.) DC. & Rubiaceae & 83 & 0.685 & 0.926 & 2.175 & 0.887 & $0.857-1.000$ \\
\hline Capparis indica (L.) Fawc. \& Druce & Capparidaceae & 19 & - & 1.090 & 0.485 & 0.815 & $0.850-1.329$ \\
\hline Cecropia peltata L. & Moraceae & 12 & 0.30 & 1.173 & 1.307 & 0.549 & $0.589-1.756$ \\
\hline Cedrela odorata L. & Meliaceae & 38 & 0.49 & 1.002 & 2.714 & 0.883 & $0.887-1.118$ \\
\hline Chomelia spinosa Jacq. & Rubiaceae & 65 & 0.72 & 1.121 & 0.174 & 0.672 & $0.959-1.282$ \\
\hline Cochlospermum vitifolium (Wild.) Spreng. & Cochlospermaceae & 90 & 0.19 & 1.067 & 2.607 & 0.600 & $0.859-1.280$ \\
\hline Cordia alliodora (R. \& P.) Oken & Boragenaceae & 43 & 0.651 & 1.245 & 0.499 & 0.273 & $0.910-1.580$ \\
\hline Cordia panamensis Riley & Boragenaceae & 32 & - & 0.978 & 1.235 & 0.727 & $0.787-1.169$ \\
\hline Dilodendron costaricense (Radlk.) Gentry \& Steyerm. & Sapindaceae & 10 & - & 0.944 & 2.210 & 0.887 & $0.685-1.202$ \\
\hline Enterolobium cyclocarpum (Jacq.) Griseb. & Fabaceae & 13 & 0.44 & 1.131 & 2.024 & 0.663 & $0.695-1.566$ \\
\hline Exostema mexicanum A. Gray & Rubiaceae & 126 & - & 0.952 & 2.248 & 0.703 & $0.860-1.044$ \\
\hline Guarea glabra Vahl. & Meliaceae & 7 & - & 0.958 & 0.806 & 0.980 & $0.802-1.114$ \\
\hline Guazuma ulmifolia Lam. & Sterculiaceae & 233 & 0.635 & 1.073 & 1.033 & 0.768 & $1.000-1.140$ \\
\hline Guettarda macrosperma Don. Sm. & Rubiaceae & 43 & - & 0.882 & 3.053 & 0.846 & $0.772-0.991$ \\
\hline Hemiangium excelsum (HBK.) Ac.Smith & Hippocrateaceae & 61 & - & 1.121 & 0.109 & 0.713 & $0.965-1.280$ \\
\hline Licania arborea Seem. & Chrysobalanaceae & 33 & 0.675 & 1.086 & 0.507 & 0.966 & $1.000-1.160$ \\
\hline Lonchocarpus costaricensis (Con.Sm.) Pitt & Fabaceae & 11 & 0.62 & 1.109 & 0.710 & 0.858 & $0.794-1.424$ \\
\hline Luehea speciosa Wild. & Tiliaceae & 381 & 0.91 & 1.100 & 0.589 & 0.902 & $1.060-1.131$ \\
\hline Machaerium biovulatum Mecheli & Fabaceae & 21 & 0.90 & 1.028 & 0.828 & 0.826 & $0.822-1.234$ \\
\hline Maclura tinctoria (L.) Don & Moraceae & 81 & 0.485 & 1.060 & 1.983 & 0.753 & $0.943-1.180$ \\
\hline Manilkara chicle (Pittier) Gilly & Sapotaceae & 37 & 0.45 & 0.979 & 1.411 & 0.931 & $0.890-1.067$ \\
\hline Myrospermum frutescens Jacq. & Fabaceae & 11 & 0.705 & 0.998 & 1.876 & 0.903 & $0.763-1.233$ \\
\hline Ocotea veraguensis (Meisn.) Mez & Lauraceae & 31 & - & 1.094 & 0.171 & 0.742 & $0.883-1.300$ \\
\hline Pisonia macranthocarpa Donn.Smith & Nyctangaceae & 28 & - & 1.009 & 0.637 & 0.857 & $0.855-1.163$ \\
\hline Pithecellobium saman (Jacq.) Benth & Fabaceae & 11 & 0.645 & 1.056 & 0.544 & 0.919 & $0.829-1.283$ \\
\hline Rehdera trinervis (Blake) Mold. & Verbenaceae & 17 & - & 0.850 & 2.691 & 0.913 & $0.713-0.988$ \\
\hline Sapium thelocarpum Schm. \& Pitt. & Euphorbiaceae & 34 & 0.50 & 1.296 & 0.383 & 0.668 & $1.022-1.570$ \\
\hline Schoepfia schreberi J.F. Gemel. & Olacaceae & 17 & 0.70 & 1.111 & 0.485 & 0.785 & $0.828-1.395$ \\
\hline Sciadodendron excelsum Griseb. & Ariliaceae & 20 & - & 1.074 & 2.882 & 0.715 & $0.790-1.359$ \\
\hline Sideroxylon capiri (A.DC.) Pitter & Sapotaceae & 10 & 0.67 & 1.050 & 1.142 & 0.901 & $0.780-1.320$ \\
\hline Simarouba glauca DC. & Simaroubaceae & 20 & 0.68 & 1.028 & 1.100 & 0.932 & $0.900-1.564$ \\
\hline Spondias mombin L. & Anacardiaceae & 144 & 0.395 & 0.906 & 2.772 & 0.723 & $0.827-0.985$ \\
\hline Tabebuea ochracea Standl. & Bignoniaceae & 55 & 0.975 & 1.050 & 0.760 & 0.852 & $0.935-1.156$ \\
\hline Tabebuea rosea (Bertol.) DC. & Bignoniaceae & 12 & 0.75 & 1.060 & 0.778 & 0.953 & $0.897-1.219$ \\
\hline Trichilia americana (Sesse \& Mocino) T.D. Penn. & Meliaceae & 20 & 0.44 & 1.004 & 1.741 & 0.778 & $0.770-1.239$ \\
\hline Trichilia cuneata Radlk. & Meliaceae & 39 & - & 0.877 & 2.240 & 0.725 & $0.724-1.030$ \\
\hline Zuelania guidonia (Sw.) Britton \& Millsp. & Flacortiaceae & 12 & - & 1.292 & -0.335 & 0.860 & $0.951-1.633$ \\
\hline
\end{tabular}

Note that $95 \%$ confidence intervals for essentially all species include the predicted slope of 1 indicating that production $\propto M^{3 / 4}$.

the optimal life history yield the approximate rule

$$
E_{\alpha} \approx \frac{(1.3) \rho^{3 / 4} M_{\alpha}^{1 / 4}}{C_{\mathrm{G}} C_{B}}
$$

for the average adult lifespan, $E_{\alpha}$, is related to size at maturation, $M_{\alpha}$. Equation (1) states that between species with similar $M_{\alpha}, E_{\alpha}$ is proportional to $\rho^{3 / 4}$. If wood density is constant, this also implies that $E_{\alpha}$ is proportional to $M_{\alpha}^{1 / 4}$. Although we are not aware of any data sets precise enough to test this prediction, qualitative support is provided by several studies showing a generally positive relationship between wood density, lifespan and age to reproduction ${ }^{4,11,19,22-24}$. In the future, one could relax the assumption $\lambda=1$ and explore the general case.

The framework developed above highlights the central roles of allometric scaling and wood density in the life histories of trees. The tropical tree species studied here varied from fast-growing disturbance specialists with low-density wood and short life spans to slow growing emergent trees with dense wood and long life spans. Despite all of this variation, production scaled as $M^{3 / 4}$, the same as in animals ${ }^{1,14}$. Although all of the tree species produced new biomass at nearly the same rates (Fig. 2b), differences in wood density resulted in substantial differences in growth rates as measured as change in basal diameter (Fig. 2a). Wood density is frequently cited as being a 'principal determinant' of life history variation in woody plants $\mathrm{s}^{11,19,22-26}$. It is correlated with stem water storage and transport capacity, resistance to decay and leaf characteristics such as toughness and deciduousness ${ }^{4,11,1922-26}$. Although the size of trees powerfully constrains rates of carbon fixation, differences in carbon allocation strategies facilitate the coexistence of multiple species in tropical forests owing to variation in growth rate, lifespan and reproductive effort ${ }^{10}$.

We have shown that a general allometric framework incorporating the specifics of vascular transport and allocation can account for numerous features of biological diversity ${ }^{14-16}$. Because of the availability of data to evaluate the model, we have focused on scaling of growth and reproduction in trees; however, the model could easily be modified for plants with different growth forms (herbs) and life histories (monocarpy). Many details of plant anatomy, physiology, and ecology (for example, water and nutrient availability, plant density) can be incorporated into the allometric coefficients (the Cs) to link pattern and process across multiple scales of biological organization. Interspecific variation in allocation to roots or defences should also be reflected in the $C$ values. Production is ultimately limited by the physical and biological constraints that limit transportation through the vascular system. However, species differ in how they allocate production. These differences in rates of growth, life span, time until reproduction, wood density and other variables can be mechanistically linked to a general allometric framework of allocation. More importantly, this framework shows how size-dependent variation in life-history strategies can be derived from a set of general allometric principles.

\section{Methods}

\section{Study area}

Measurements of diameters at breast height (dbh) of trees were recorded within a permanently marked study plot of seasonally dry tropical forest $\left(10^{\circ} 45^{\prime} \mathrm{N}, 85^{\circ} 30^{\prime} \mathrm{W}\right)$ 
within Sector Santa Rosa, Area de Conservacion, Guanacaste (ACG), of northwest Costa Rica $^{27}$. In 1976, all stems $\geq 3 \mathrm{~cm}$ dbh were mapped within a continuous $680 \mathrm{~m} \times 240 \mathrm{~m}$ $\left(16.32 \mathrm{Ha}\right.$ ) area of forest ${ }^{20}$ by S. P. Hubbell. Using an identical mapping protocol, a second remap of the San Emilio forest was completed between 1995 and 1996. In total, 46,833 individuals have been surveyed, 26,960 in 1976 and 19,873 in 1996. Together, the two surveys document $20 \mathrm{yr}$ of growth and population change for about 150 species. The plot is composed of secondary growth forest and is heterogeneous with respect to age, topography and degree of deciduousness.

\section{Calculation of individual tree growth}

In 1976, most trees greater than $10 \mathrm{~cm}$ dbh were tagged with aluminum tree markers and given a unique identification number. Because few smaller individuals were given aluminum tags in 1976, tree growth was usually followed only for those trees greater than $10 \mathrm{~cm}$ dbh. Growth was calculated by monitoring changes in dbh for each individual. To ensure an accurate estimate of growth, a species was included only if a minimum representation of seven individuals had initial stem diameters $\geq 10 \mathrm{~cm}$, and the diameter range of all individuals $\geq 20 \mathrm{~cm}$. As the minimum diameter cut off for individuals was $10 \mathrm{~cm}$, this imposed a minimum size range of $30 \mathrm{~cm}$. Only individuals experiencing positive growth in the 20-year period were used for the calculation of allometric equations. In some cases, individuals experienced no change or even a decrease in diameter over time. This was usually due to partial death, loss of the main trunk or measuring errors. The 45 species meeting the above criteria are listed in Table 1. Production equations for each species were generated by plotting $D^{2 / 3}(0)$ versus $D^{2 / 3}(20)$ on linear axes. Because dbh was measured identically in 1976 and 1996, measurement error is likely to be equally distributed across the $x$ and $y$ axes. For these reasons, allometric slopes were determined using Model II RMA regression ${ }^{1,28,29}$. Equations and statistics for each species are also reported in Table 1.

\section{Species-specific wood density}

The specific wood density, $\rho$, is a simple measure of the total dry mass per unit volume of wood $\left(\mathrm{g} \mathrm{cm}^{-3}\right)$. The specific density of wood is closely related to mechanical properties of strength, such as elastic moduli, which describe resistance to static and impact bending, compression and tension ${ }^{28}$. For 29 of the 45 species reported in this study, values of specific wood density, $\rho$, in $\mathrm{g} \mathrm{cm}^{-3}$, were taken from the literature $e^{24,26,30}$. If more than one study reported a different value for a species, then the average value was used (Table 1).

Received 9 June; accepted 12 August 1999.

1. Charnov, E. L. Life History Invariants: Some Explorations of Symmetry in Evolutionary Ecology (Oxford Univ. Press, Oxford, 1993).

2. Stearns, S. C. The Evolution of Life Histories (Oxford Univ. Press, Oxford, 1992)

3. Richards, P. W. The Tropical Rain Forest 2nd edn (Cambridge Univ. Press, Cambridge, 1996).

4. Chambers, J. Q., Higuchi, N. \& Schimel, J. P. Ancient trees in Amazonia. Nature 391, 135-136 (1998).

5. Grime, J. P. \& Hunt, R. Relative growth-rate: its range and adaptive significance in a local flora. J. Ecology 63, 393-422 (1975)

6. Tilman, D. Plant Strategies nd the Dynamics and Structure of Plant Communities (Princeton Univ. Press, Princeton, 1988).

7. Cebran, J. \& Duarte, C. M. The dependence of herbivory on growth rate in natural plant communities. Func. Ecol. 8, 518-525 (1994).

8. Gleeson, S. K. \& Tilman, D. Plant allocation, growth rate and successional status. Func. Ecol. 8, $543-$ 550 (1994).

9. Ricklefs, R. E. Environmental heterogeneity and plant species diversity: an hypothesis. Am. Nat. 111, 376-381 (1977).

10. Grubb, P. J. The maintenance of species diversity in plant communities: the importance of the regeneration niche. Biol. Rev. 52, 107-145 (1977).

11. Denslow, J. S. Gap partitioning among tropical rain forest trees. Biotropica (Suppl.), 12, 47-55 (1980). 12. Williamson, G. B. Gradients in wood specific gravity of trees. Bull. Torr. Bot. Club 111, 51-55 (1996).

13. Hubbell, S. P. et al. Light-gap disturbances, recruitment limitation, and tree diversity in a neotropical forest. Science 283, 554-557 (1999).

14. West, G. B., Brown, J. H. \& Enquist, B. J. A general model for the origin of allometric scaling laws in biology. Science 276, 122-126 (1997).

15. Enquist, B. J., Brown, J. H. \& West, G. B. Allometric scaling of plant energetics and population density. Nature 395, 163-165 (1998)

16. West, G. B., Brown, J. H. \& Enquist, B J. A general model for the structure and allometry of plant vascular systems. Nature 400, 664-667 (1999).

17. Peters, R. H. et al. The allometry of the weight of fruit on trees and shrubs in Barbados. Oecologia 74, 612-616 (1988).

18. Niklas, K. The allometry of plant reproductive biomass and stem diameter. Am. J. Bot. 80, 461-467 (1993).

19. Thomas, S. C. Reproductive allometry in Malaysian rain forest trees: biomechanics verses optimal allocation. Evol. Ecol. 10, 517-530 (1996).

20. Stevens, G. C. Lianas as structural parasites: the Bursera simaruba example. Ecol. 68, 77-81 (1987).

21. Whittaker, R. H. \& Woodwell, G. M. Dimension and production relations of trees and shrubs in the Brookhaven Forest, New York. Ecology 56, 1-25 (1968).

22. Smith, D. W. \& Tumey, P. R. Specific density and caloric value of the trunk wood of white birch, black cherry, and sugar maple and their relationship to forest succession. Can. J. For. Res. 12, 186-190 (1982)

23. Augspurger, C. K. Seed dispersal of the tropical tree Platyposdium elegans and the escape of its seedlings from fungal pathogens. J. Ecol. 71, 759-771 (1983).

24. Borchert, R. Soil and stem water storage determine phenology and distribution of Dry Tropical forest trees. Ecology 75, 1437-1449 (1994).

25. Sobrado, M. A. Aspects of tissue water relations of evergreen and seasonal changes in leaf water potential components of evergreen and deciduous species coexisting in tropical forests. Oecologia 68, 413-416 (1986).

26. Fearnside, P. M. Wood density for estimating forest biomass in Brazilian Amazonia. For. Ecol. Manage
90, 59-87 (1997).

27. Janzen, D. H. Guanacaste National Park: Tropical Education, and Cultural Restoration (Editorial Univ. Estatal a Distanca, San Jose, 1986).

28. Niklas, K. J. Plant Allometry: The Scaling of Form and Process (Univ. Chicago Press, Chicago, 1994). 29. Harvey, P. H. \& Pagel, M. D. The Comparative Method in Evolutionary Biology (Oxford Univ. Press, Oxford, 1991).

30. Malavassi, I. C. Maderas de Costa Rica: 150 Especies Forestales (Univ. de Costa Rica, San Jose, 1998).

\section{Acknowledgements}

We thank R. J. Whittaker, G. C. Stevens, D. H. Janzen, J. J. Sullivan, L. Brown, C. A. F. Enquist, A. Masis and the A.C.G. for comments and help with data collection. B.J.E. was supported by a NSF postdoctoral fellowship, G.B.W. by the US Department of Energy and the NSF, E.L.C. by a MacArthur fellowship and J.H.B. by a University of New Mexico Faculty Research Semester. B.J.E., G.B.W. and J.H.B. were also supported by the Thaw Charitable Trust.

Correspondence and requests for materials should be addressed to B.J.E.

(e-mail: enquist@nceas.ucsb.edu).

\section{Optimizing the success of random searches}

\section{G. M. Viswanathan ${ }^{\star} \ddagger$, Sergey V. Buldyrev ${ }^{\star}$, Shlomo Havlin* $\$, M. G. E. da Luz $\|$, E. P. Raposo $\| \#$ \& H. Eugene Stanley}

* Center for Polymer Studies and Department of Physics, Boston University, Boston, Massachusetts 02215, USA

$\dagger$ International Center for Complex Systems and Departamento de Física Teórica e Experimental, Universidade Federal do Rio Grande do Norte, 59072-970,

Natal-RN, Brazil

$\ddagger$ Departamento de Física, Universidade Federal de Alagoas, 57072-970,

Maceió-AL, Brazil

$\$$ Gonda-Goldschmied Center and Department of Physics, Bar Ilan University, Ramat Gan, Israel

Il Lyman Laboratory of Physics, Harvard University, Cambridge,

Massachusetts 02138, USA

- Departamento de Física, Universidade Federal do Paraná, 81531-970,

Curitiba-PR, Brazil

\# Laboratório de Física Teórica e Computacional, Departamento de Física, Universidade Federal de Pernambuco, 50670-901, Recife-PE, Brazil

We address the general question of what is the best statistical strategy to adapt in order to search efficiently for randomly located objects ('target sites'). It is often assumed in foraging theory that the flight lengths of a forager have a characteristic scale: from this assumption gaussian, Rayleigh and other classical distributions with well-defined variances have arisen. However, such theories cannot explain the long-tailed power-law distributions $^{1,2}$ of flight lengths or flight times ${ }^{3-6}$ that are observed experimentally. Here we study how the search efficiency depends on the probability distribution of flight lengths taken by a forager that can detect target sites only in its limited vicinity. We show that, when the target sites are sparse and can be visited any number of times, an inverse square power-law distribution of flight lengths, corresponding to Lévy flight motion, is an optimal strategy. We test the theory by analysing experimental foraging data on selected insect, mammal and bird species, and find that they are consistent with the predicted inverse square power-law distributions.

Lévy flights are characterized by a distribution function

$$
P\left(l_{\mathrm{j}}\right) \sim l_{\mathrm{j}}^{-\mu}
$$

with $1<\mu \leq 3$, where $l_{\mathrm{j}}$ is the flight length. The gaussian is the stable distribution for the special case $\mu \geq 3$ owing to the centrallimit theorem, while values $\mu \leq 1$ do not correspond to probability distributions that can be normalized ${ }^{2}$. This generalization, equation (1), introduces a natural parameter $\mu$ such that we essentially have a 
. Tao, Y. et al. Assembly of a tailed bacterial virus and its genome release studied in three dimensions. Cell 95, 431-437 (1998).

6. Valpuesta, J. M. \& Carrascosa, J. L. Structure of viral connectors and their function in bacteriophage assembly and DNA packaging. Q. Rev. Biophys. 27, 107-155 (1994).

7. Guo, P., Erickson, S. \& Anderson, D. A small viral RNA is required for in vitro packaging of bacteriophage $\$ 29$ DNA. Science 236, 690-694 (1987).

8. Zhang, F. et al. Function of hexameric RNA in packaging of bacteriophage $\$ 29$ DNA in vitro. Mol. Cell 2, 141-147 (1998).

9. Guo, P., Zhang, C., Chen, C., Garver, K. \& Trottier, M. Inter-RNA interaction of phage $\phi 29 \mathrm{pRNA}$ to form a hexameric complex for viral DNA transportation. Mol. Cell 2, 149-155 (1998).

10. Müller, D. J., Engel, A., Carrascosa, J. L. \& Vélez, M. The bacteriophage $\phi 29$ head-tail connector imaged at high resolution with the atomic force microscope in buffer solution. EMBO J. 16, 25472553 (1997).

11. Valpuesta, J. M., Fernández, J. J., Carazo, J. M. \& Carrascosa, J. L. The three-dimensional structure of a DNA translocating machine at 10 A resolution. Structure 7, 289-296 (1999).

12. Valle, M. et al. Domain architecture of the bacteriophage $\phi 29$ connector protein. J. Mol. Biol. 288, 899-909 (1999).

13. Guasch, A. et al. Crystallographic analysis reveals the 12 -fold symmetry of the bacteriophage $\phi 29$ connector particle. J. Mol. Biol. 281, 219-225 (1998)

14. Badasso, M. O. et al. Purification, crystallization, and initial X-ray analysis of the head-tail connector of bacteriophage $\phi 29$. Acta Crystallogr. D 56, 1187-1190 (2000).

15. Vlcek, C. \& Paces, V. Nucleotide sequence of the late region of Bacillus $\phi 29$ completes the 19285-bp sequence of $\$ 29$ genome. Comparison with the homologous sequence of phage PZA. Gene 46, 215 225 (1986).

16. Grimes, S. \& Anderson, D. RNA dependence of the bacteriophage $\phi 29$ DNA packaging ATPase. J. Mol Biol. 215, 559-566 (1990).

17. Donate, L. E., Valpuesta, J. M., Mier, C., Rojo, F. \& Carrascosa, J. L. Characterization of an RNAbinding domain in the bacteriophage $\phi 29$ connector. J. Biol. Chem. 268, 20198-20204 (1993).

18. Reinisch, K. M., Nibert, M. L. \& Harrison, S. C. Structure of the reovirus core at $3.6 \AA$ resolution. Nature 404, 960-967 (2000).

19. Ibarra, B. et al. Topology of the components of the DNA packaging machinery in the phage $\phi 29$ prohead. J. Mol. Biol. 298, 807-815 (2000).

20. Guo, P., Peterson, C. \& Anderson, D. Prohead and DNA-gp3-dependent ATPase activity of the DNA packaging protein gp16 of bacteriophage $\phi 29$. J. Mol. Biol. 197, 229-236 (1987).

21. Dube, P., Tavares, P., Lurz, R. \& van Heel, M. The portal protein of bacteriophage SPP1: a DNA pump with 13-fold symmetry. EMBO J. 12, 1303-1309 (1993).

22. Abrahams, J. P., Leslie, A. G. W., Lutter, R. \& Walker, J. E. Structure at $2.8 \AA$ resolution of $\mathrm{F}_{1}$-ATPase from bovine heart mitochondria. Nature 370, 621-628 (1994).

23. Silverman, M. R. \& Simon, M. I. Flagellar rotation and the mechanism of bacterial motility. Nature 249, 73-74 (1974).

24. Vale, R. D. \& Milligan, R. A. The way things move: looking under the hood of molecular motor proteins. Science 288, 88-95 (2000)

25. Rossmann, M. G. \& Arnold, E. International Table for Crystallography Vol. F (International Union of Crystallography, Kluwer Academic, Dordrecht) (in the press).

26. Baker, T. S. \& Cheng, R. H. A model-based approach for determining orientations of biological macromolecules imaged by cryoelectron microscopy. J. Struct. Biol. 116, 120-130 (1996).

27. Bailey, S. et al. Phylogenetic analysis and secondary structure of the Bacillus subtilis bacteriophage RNA required for DNA packaging. J. Biol. Chem. 265, 22365-22370 (1990).

28. Reid, R. J. D., Bodley, J. W. \& Anderson, D. Identification of bacteriophage $\$ 29$ prohead RNA domains necessary for in vitro DNA-gp3 packaging. J. Biol. Chem. 269, 9084-9089 (1994).

\section{Acknowledgements}

We thank J. Carrascosa for comments and discussions of this paper. We also thank the staff of CHESS, APS BioCARS and APS Structural Biology Center for assistance in data collection. This work was supported by the NSF (M.G.R.), the NIH (D.L.A. and T.S.B.), and an NSF Shared Instrumentation grant (T.S.B. and M.G.R).

Correspondence and requests for materials should be addressed to M.G.R. (e-mail: mgr@indiana.bio.purdue.edu). Coordinates of the connector (accession number 1FOU) and pRNA (accession number 1FOQ) have been deposited with the Protein Data Bank.

\section{errata}

\section{Logical computation using algorithmic self-assembly of DNA triple-crossover molecules}

Chengde Mao, Thomas H. LaBean, John H. Reif \& Nadrian Seeman

Nature 407, 493-496 (2000).

In Fig. 2 of this paper, $y_{2}$ should have equalled 0 in Calculation 1; and $\mathrm{x}_{2}, \mathrm{y}_{3}$ and $\mathrm{y}_{4}$ should have equalled 0 in Calculation 2.

\section{Acceleration of global warming due to carbon-cycle feedbacks in a coupled climate model}

Peter M. Cox, Richard A. Betts, Chris D. Jones, Steven A. Spall

\& lan J. Totterdell

Nature 408, 184-187 (2000).

In this paper, part of the labelling of Figs $2-4$ was printed incorrectly. In Fig. 2, the year 2950 should have been 2050. In Figs 2 and 3, the year 1050 should have been 1950. In Fig. 4, the numbers on the $y$ axis should have been labelled sequentially from -200 to +400 ; in addition, in Fig. 4 a the $y$ axis should have been labelled 'Changes in vegetation carbon (Gt C)'.

\section{correction}

\section{Allometric scaling of production and life-history variation in vascular plants}

\author{
Brian J. Enquist, Geoffrey B. West, Eric L. Charnov \\ \& James H. Brown
}

Nature 401, 907-911 (1999).

In the last sentence of the abstract the relative growth rate equation, presented as $(1 / M)(\mathrm{d} M / \mathrm{d} f)$, should read $(1 / M)(\mathrm{d} M / \mathrm{d} t)$. Also, the sentence following that containing equation (5) should read "Thus, regardless of any possible time dependence of either the proportionality constants or the density, a plot of $M^{1 / 4}$ versus $M_{0}^{1 / 4}$ for fixed times $t$ and $t_{0}$ for any species should yield a straight line with a universal slope of unity but with an intercept that depends on the time interval and the species."

In other words, the primary relationship is in terms of mass, $M$ and not diameter, D. Equations (4) and (5), which relate the dependence of trunk diameter, $D$, on time, $t$, are only valid if the proportionality constant $A \equiv C_{D} / \rho^{3 / 8}$ is time-independent; $A$ is the proportionality constant in the allometric relation $D=A M^{3 / 8}$ of equation (3). This is needed because data are typically given in terms of $D$ rather than $M$. The other proportionality constants, $C_{G}$ and $C_{B}$, occurring, respectively, in the growth equation (2) and allometric equation for metabolic rate (3), can be time-dependent.

As our analysis of the data assumed time-independence of all of these coefficients as well as of wood density, $\rho$ (see below equation (6)), this oversight does not affect our results or conclusions. If $A$ were slowly varying, it would contribute a small correction to the unit slope prediction given by $\left(t-t_{0}\right) d$, where $d$ is the logarithmic derivative of $A$. This is expected to be very small, especially as the time interval $\left(t-t_{0}\right)$ is small relative to the lifespan of the species sampled. Furthermore, any time dependence in $A$ is almost certainly smaller than its variation across species and effects arising from neglecting maintenance costs in the growth equation (2). We thank J. Banavar, J. Damuth, A. Maritan and A. Rinaldo for bringing this oversight to our attention. 